\title{
Reduction of nitrous oxide emission by a smaller air to fuel ratio in a large-scale sewage sludge fluidized bed combustor
}

\author{
L. D. Korving ${ }^{1}$, C. Schilt ${ }^{2} \&$ W. De Jong ${ }^{2}$ \\ ${ }^{1}$ Slibverwerking Noord-Brabant, The Netherlands \\ ${ }^{2}$ Process \& Energy Laboratory, Delft University of Technology, \\ The Netherlands
}

\begin{abstract}
A full-scale experimental study showed a $70 \%$ reduction of the nitrous oxide emission from the combustion of sewage sludge by a smaller air-to-fuel ratio. The experiments were performed on the furnaces of one of Europe's largest sludge-incinerators, Slibverwerking Noord-Brabant. The results were implemented in the daily operation and they significantly reduced the emission of nitrous oxides without increasing emissions, such as $\mathrm{NO}_{x}$ and $\mathrm{NH}_{3}$. The study showed a correlation between the $\mathrm{NO}_{\mathrm{x}}$ emission and the bed temperature, while the $\mathrm{N}_{2} \mathrm{O}$ emission correlates to the free board temperature. With the lower air-fuel ratio the bed temperature could be maintained at constant levels while increasing the temperature in the freeboard, thus achieving a reduced $\mathrm{N}_{2} \mathrm{O}$ emission without increasing the $\mathrm{NO}_{\mathrm{x}}$ emission. The lower air input also reduces the energy use of the forced and induced draught fans, giving a substantial financial benefit. A simplified chemical reactor model was set up for the freeboard of the furnace. The model fits with the experimental results of in-furnace measurements. In addition, a hypothetical case shows that improving the reactor via a Plug Flow Reactor configuration is most beneficial.
\end{abstract}

Keywords: nitrous oxide, nitrogen oxides formation, fluidized bed combustion, air-fuel ratio, sewage sludge, temperature, lambda factor. 


\section{Introduction}

In the last decade there has been a growth in the incineration of sewage sludge. In the past this sludge was mainly used as a fertilizer in agriculture, but contamination of the sludge with heavy metals and organic pollutants, especially persistent organic pollutants (POPs), has raised concern as to whether the sludge can be used safely as a fertilizer. In The Netherlands the use of sewage sludge in agriculture has not been possible since 1995. In other European countries and according to European directives sewage sludge can be used in agriculture. Nevertheless, there is an increasing trend to incinerate the sludge, especially in Northern Europe. The sludge can be incinerated in mono-incineration plants for sewage sludge or co-incinerated in coal fired power plants or cement kilns. Mono-incineration of sewage sludge produces a fly ash that can be used as a filler material in road construction. The fly ash is rich in phosphates and recent research $[1,2]$ has produced promising propositions to recycle these phosphates, thus enabling the conservation of a scarce resource in a safe manner.

Mono-incineration of sewage sludge is mainly performed in bubbling fluidized bed furnaces, as these furnaces have proven to reliably incinerate sludges with low heating values (3-4 MJ/kg). The high nitrogen content of sewage sludge (40-60 g/kg dry matter) makes the management of the nitrogen based emissions $\left(\mathrm{NO}_{\mathrm{x}}, \mathrm{N}_{2} \mathrm{O}\right.$ and $\left.\mathrm{NH}_{3}\right)$ a point of attention. Strict emission limits for the emission of $\mathrm{NO}_{\mathrm{x}}$ and $\mathrm{NH}_{3}$ have drawn the most attention to the optimisation of the incineration. The emission of $\mathrm{N}_{2} \mathrm{O}$ receives little attention and is often not measured. Nevertheless the emission of this strong greenhouse gas can contribute significantly to the $\mathrm{CO}_{2}$-footprint of sewage sludge incineration.

For this reason this study focuses on the emission of $\mathrm{N}_{2} \mathrm{O}$ and methods to reduce this emission. The experiments have been performed on the four fluidized bed furnaces of Slibverwerking Noord-Brabant (SNB) in Moerdijk.

\section{Process description}

SNB operates four incineration lines for the treatment of sewage sludge from municipal waste water treatment plants. On an annual basis 420000 tons of wet sludge (100 $000 \mathrm{t} / \mathrm{y}$ as dry matter) is incinerated in the installation. This amount represents $28 \%$ of the total sludge production in The Netherlands and is produced in more than 70 waste water treatment plants representing a total capacity of approximately 8 million people equivalents. The installation is one of the largest sludge incinerators in Europe.

After pre-drying the sludge to a dry matter content of $35-40 \%$ the sewage sludge is combusted in four identical bubbling fluidized bed furnaces. The bed temperature is normally maintained between 800 and $850^{\circ} \mathrm{C}$. The freeboard temperature is maintained within a range of 890 to $940^{\circ} \mathrm{C}$. The total freeboard volume amounts to circa $116 \mathrm{~m}^{3}$ giving a residence time of more than 3 seconds.

Limestone is added to the furnace to capture $\mathrm{SO}_{2}$ that is formed in the furnace. It reacts via calcium oxide to anhydrite $\left(\mathrm{CaSO}_{4}\right)$ that leaves the furnace together with the fly ash. Part of the calcium oxide and anhydrite remain in the 
furnace and make up a large part of the bed material. A diluted ammonia solution is injected at the top of the furnace to control the emission of $\mathrm{NO}_{\mathrm{x}}$ (figure 1). Characteristic for the incineration of sewage sludge is the large degree of volatiles giving a large temperature difference between the bed and the freeboard. The dry matter in the sludge has an ash content of $32 \%$ giving a large fly ash production. The ash has a high content of calcium, iron and aluminium. These will be present as oxides or phosphates.

\section{Theoretical backgrounds}

\subsection{Literature review}

Little open literature is available that gives a good detailed description of the combustion of semi-dried sewage sludge in a fluidized bed incinerator. Most experiments have been performed with dried sludge (dry matter $>80 \%$ ), but this sludge has a different emission pattern when compared to semi-dry (dry matter $30-55 \%$ ) or mechanically dewatered sludge (dry matter $20-40 \%$ ) as described by Werther and Ogada [3]. Sänger et al. [4] describe the effects of the drying of sludge on the combustion characteristics and especially the emission of $\mathrm{NO}_{\mathrm{x}}$ and $\mathrm{N}_{2} \mathrm{O}$. They describe the results of combustion experiments in a semi-pilot fluidized bed incinerator as well as an industrial fluidized bed incinerator. This study, as well as the overview article of Werther and Ogada [3] that cites results of studies from the Technical University of Hamburg-Harburg by Ogada [5] and Philippek [6], prove that the emission of nitrogen compounds can differ when the combustion of dried sludge is compared to the combustion of semi-dried or dewatered sludge. When combusting (semi-)wet sludge the $\mathrm{NO}_{\mathrm{x}}$-emission will generally be lower while the $\mathrm{N}_{2} \mathrm{O}$-emission will be significantly higher. These

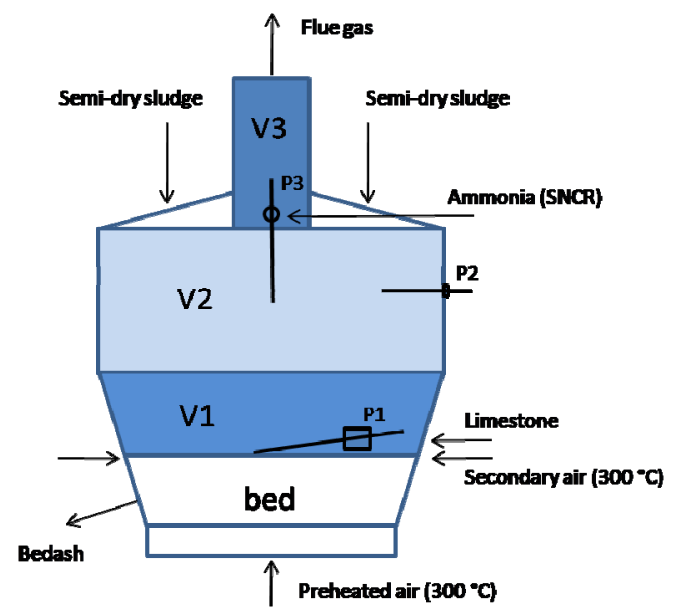

Figure 1: $\quad$ Sketch of the SNB-furnace with reactor volumes V1, V2 \& V3 and probing locations P1, P2 \& P3. 
studies also showed that emission reduction strategies that are valid for dried sludge will not be applicable for (semi-)wet sludge. For instance, the emission of $\mathrm{NO}_{\mathrm{x}}$ will decrease when the air-to-fuel ratio is reduced because of an increase of $\mathrm{NH}_{3}$ in the reducing zones of the combustion process resulting in a de- $\mathrm{NO}_{\mathrm{x}}$ reaction with NO that has already been formed. Wet sludge on the other hand is characterized by so much $\mathrm{NH}_{3}$ dissolved in the water phase that this same trend is not true for this type of sludge: a lower air-to-fuel ratio will only give less dilution of the produced $\mathrm{NO}_{\mathrm{x}}$. Suzuki et al. [7] report similar trends for the pressurized combustion in a fluidized bed pilot set-up.

Abelha et al. [8] recently gave a useful schematic of the nitrogen-chemistry for the conversion of solid fuels. The initial conversion process after evaporation is pyrolysis. For biofuels the formation of volatile- $\mathrm{N}$ is more important than char-N. An increase in temperature will show an increase of bound nitrogen in the volatile fraction. Abeldha et al. also prove this for sewage sludge though for dried pellets. They also proved that higher temperatures will result in a higher ratio of $\mathrm{HCN} / \mathrm{NH}_{3}$. Another important parameter for the pyrolysis phase is the $\mathrm{O} / \mathrm{N}$ ratio in the fuel as described by Aho $[9,10]$. These studies show that a low $\mathrm{O} / \mathrm{N}$ ratio in the fuel results in a high $\mathrm{HCN} / \mathrm{NH}_{3}$-ratio during the pyrolysis phase. Winter et al. [11] confirmed these conclusions. Sewage sludge shows a low $\mathrm{O} / \mathrm{N}$ ratio compared to woody biomass and this could explain the relatively high $\mathrm{N}_{2} \mathrm{O}$ emission since $\mathrm{HCN}$ is seen as the most important precursor for $\mathrm{N}_{2} \mathrm{O}$ as described for instance by Kramlich et al. [12] and Kilpinen and Hupa [13].

After and partly simultaneously with the pyrolysis process there will be a further oxidation of the pyrolysis products. Homogeneous oxidation of $\mathrm{NH}_{3}$ leads to $\mathrm{NO}$ via $\mathrm{NH}_{\mathrm{i}}$-radicals. The reduction to harmless $\mathrm{N}_{2}$ is possible with already formed NO. In addition heterogeneous reduction is possible on catalytic surfaces, mainly on $\mathrm{Ca}$ and Fe containing ash or char particles. $\mathrm{HCN}$ oxidizes homogeneously to $\mathrm{NO}$, but also significantly to $\mathrm{N}_{2} \mathrm{O}$. Reduction as well as oxidation to NO can also take place on the already mentioned catalytic surfaces. $\mathrm{NO}$ can be reduced heterogeneously by $\mathrm{NH}_{3}$ but also by $\mathrm{CO}$. The emission of $\mathrm{N}_{2} \mathrm{O}$ can be significantly reduced homogeneously by increasing the temperature to levels above $900^{\circ} \mathrm{C}$. Char and more in general bed material and fly ash can catalyze this reduction as described by Barisic et al. [14], although water that is abundantly present in the flue gas will act as an inhibitor. Nevertheless too high temperatures (above $950^{\circ} \mathrm{C}$ ) are not acceptable for several reasons. Firstly, the higher temperatures will give an increase of the emission of $\mathrm{NO}_{\mathrm{x}}$ and the emission of this component is heavily regulated. Secondly higher temperatures give an increased risk of melting of the fly ash and consequently fouling of the steam boiler. Thirdly higher temperatures of the fluidized bed significantly decrease the efficiency of the limestone injection in the furnace for the reduction of the emission of $\mathrm{SO}_{2}$.

\subsection{Simplified chemical reactor model}

A simplified chemical reactor model was set up to gain more understanding of the decomposition of $\mathrm{N}_{2} \mathrm{O}$ in the furnace. The modelling study was accomplished with the chemical simulation software ChemKin 4.1.1. The reaction scheme 
KILPINEN 97 [15], consisting of kinetic mechanisms and thermodynamic data, was used for modelling the freeboard reactions. It consists of 371 homogeneous gas phase reactions with relation to biomass combustion and provides relations between $\mathrm{NH}_{3}$ and $\mathrm{HCN}$ for the formation and destruction of $\mathrm{N}_{2} \mathrm{O}$. The freeboard was modelled as a Perfectly Stirred Reactor (PSR), Plug Flow Reactor (PFR) and a combination of a Perfectly Stirred and Plug Flow Reactor (PSR+PFR). For this last combination figure 1 shows the reactor volumes V1 $\left(33 \mathrm{~m}^{3}\right)$ and V2 $\left(68 \mathrm{~m}^{3}\right)$ that were simulated as a PSR and volume V3 $\left(15 \mathrm{~m}^{3}\right)$ that was simulated as a PFR. This selection was based on an evaluation of the Peclet-numbers in the furnace and should best describe the mixing conditions in these volumes. The results of the in-furnace measurements at probing location P1 were taken as input conditions (see following paragraph).

\section{Experiments}

\subsection{In-furnace measurements}

During five days in-furnace measurements have been performed with a specially developed cooled probing lance to determine typical gas compositions at different places and residence times in the furnace. The measurements were performed at three different probing locations as shown in figure 1:

- P1: probe location via a viewing window just above the fluidized bed.

- P2: probe location half way the furnace close to the sludge feeding point (sludge is fed to the furnace from two points on the top of the furnace).

- P3: probe location on top of the furnace via the normal injection point for the ammonia injection.

The gas samples were sucked out via the probing lance. By cooling of the lance the gas composition was maintained in the lance. The gas composition was analysed with an FTIR-analyzer (Nicolet 560 with a $2 \mathrm{~m}$ optical gas cell kept at $150^{\circ} \mathrm{C}$ ). Gas temperatures were measured with a second pyrometer probe.

\subsection{Step change experiments}

Experiences in earlier experiments and from daily operation showed that a lower air-to-fuel ratio tended to show a lower $\mathrm{N}_{2} \mathrm{O}$-emission. To quantify this effect step changes to the furnace oxygen excess setpoint were made. The setpoint for the oxygen excess level was varied from $6 \mathrm{vol} \%$ (wet basis) to $4 \mathrm{vol} \%$ in steps of 0,5 vol $\%$. Two runs were made. In the first run each step change lasted 24 hours before a next step in the oxygen excess setpoint was made. In the second run each step change lasted 12 hours. During the first run the operators were allowed to inject ammonia to reduce the $\mathrm{NO}_{\mathrm{x}}$-concentrations. As the first run proved that the furnaces could be operated without ammonia injection within the legal $\left(\mathrm{NO}_{\mathrm{x}}\right)$ limits, the second run was performed without ammonia injection.

The experiments were performed on one of the four furnaces of SNB during normal operation. The operators maintained the temperatures in the furnaces within the normal limits (bed temperature between $800-840^{\circ} \mathrm{C}$ and freeboard 
temperature between $890-940^{\circ} \mathrm{C}$ ) by controlling the pre-drying of the sludge and/or varying the air pre-heat temperature between 250 and $300^{\circ} \mathrm{C}$ (normal setpoint for the temperature is $300^{\circ} \mathrm{C}$ ). Sludge throughputs during the test were normal, i.e. the furnace was operated at $100 \%$ capacity.

The normal continuous emission measurement system in the stack of the incineration line was used to analyze the effect on the emissions. These analyzers are IR-analyzers measuring in hot and wet gas (SICK MCS 100 E HW). For unburned hydrocarbons an FID-analyzer is used.

\subsection{Implementation in daily operation}

Already in 2006 SNB reduced the air-to-fuel ratio on its furnaces by reducing the setpoint for the oxygen excess level from $6 \mathrm{vol} \%$ (wet gas) to $5 \mathrm{vol} \%$. This reduction proved to have a positive effect on the reduction of the emission of $\mathrm{N}_{2} \mathrm{O}$ from the furnaces and was the reason for the current more systematic study. Based on the positive results of this study a second reduction of the air-to-fuel ratio was implemented in September 2009 by further lowering the setpoint for the oxygen excess level from 5 vol\% to 4 vol\%.

\section{Results}

\subsection{In-furnace measurements}

Table 1 shows the averaged results of the in-furnace measurements at the different probing locations (concentrations normalized to a constant oxygen level of $11 \mathrm{vol} \%$ ). The measurements show significant concentrations of HCN just above the fluidized bed as well as high concentrations of $\mathrm{N}_{2} \mathrm{O}$. HCN is nearly disappeared at P2 and not detectable at P3. The $\mathrm{NO}$ and $\mathrm{N}_{2} \mathrm{O}$ concentrations show a decreasing trend but remain present in significant concentrations at the top of the furnace. During all measurements the temperatures in the fluidized bed and the furnace were kept as constant as possible. During all measurements the oxygen concentration in the furnace was maintained at $5 \mathrm{vol} \%$ (wet basis). During one measurement at P3 the oxygen level was first raised to 5,5 vol\% and then lowered to $4,5 \mathrm{vol} \%$. This experiment showed an increase of the $\mathrm{N}_{2} \mathrm{O}$ concentration when the oxygen level was increased and a decrease when the

Table 1: $\quad$ Results of in-furnace measurements $\left(\mathrm{mg} / \mathrm{Nm}^{3}\right.$ dry gas at $\left.11 \% \mathrm{O}_{2}\right)$.

\begin{tabular}{|c|c|c|c|c|c|c|}
\hline Probing location: & \multicolumn{2}{|c|}{$\mathrm{P} 1$} & P2 & \multicolumn{3}{c|}{ P3 } \\
\hline Run: & Run a & Run b & Run a & Run a & Run b & Run c \\
\hline $\mathrm{O}_{2}$ (vol\%, wet) & 5 & 5 & 5 & 5 & 5,5 & 4,5 \\
\hline Temperature $\left({ }^{\circ} \mathrm{C}\right)$ & \multicolumn{2}{|c|}{$850-880$} & $900-910$ & $900-910$ & $895-905$ & $910-930$ \\
\hline $\mathrm{HCN}$ & 284 & 277 & 25 & 0 & 0 & 0 \\
\hline $\mathrm{NO}$ & 139 & 131 & 85 & 53 & 47 & 75 \\
\hline $\mathrm{N}_{2} \mathrm{O}$ & 544 & 497 & 346 & 257 & 356 & 170 \\
\hline
\end{tabular}


oxygen level was decreased. The lower oxygen level also showed an increase in the emission of NO. The increase in the air-to-fuel ratio resulted in slightly lower furnace temperatures, whereas the decrease in the air-to-fuel ratio resulted in furnace temperatures that were $10-20^{\circ} \mathrm{C}$ higher.

For practical reasons the measurement runs at the different probing locations could not be performed at the same time, but were distributed over five measuring days. Although the conditions in the furnace were kept as constant as possible there was some variation in for instance the heating value of the sludge and consequently in furnace temperatures. Nevertheless it was attempted to normalize all measurements to a similar basis to enable a comparison between the measurements. For all measurements also the $\mathrm{N}_{2} \mathrm{O}$ emissions in the stack were monitored with the regular emission measurement system. As this measurement location was common to all measurements it was postulated that a higher $\mathrm{N}_{2} \mathrm{O}$-emission in the stack would also mean correspondingly higher $\mathrm{N}_{2} \mathrm{O}$ concentrations upstream in the furnace. With this assumption all measurement results were expressed as a relative concentration to the stack emission. As HCN is an important precursor to $\mathrm{N}_{2} \mathrm{O}$ the $\mathrm{HCN}$ concentrations were also expressed as $\mathrm{N}_{2} \mathrm{O}$-equivalents taking into account the stoichiometric ratio of $1 \mathrm{~mol} \mathrm{~N}_{2} \mathrm{O}$ for 2 moles HCN. This procedure produced the result in figure 2 and shows a surprisingly good correlation of all data with the residence time in the furnace.

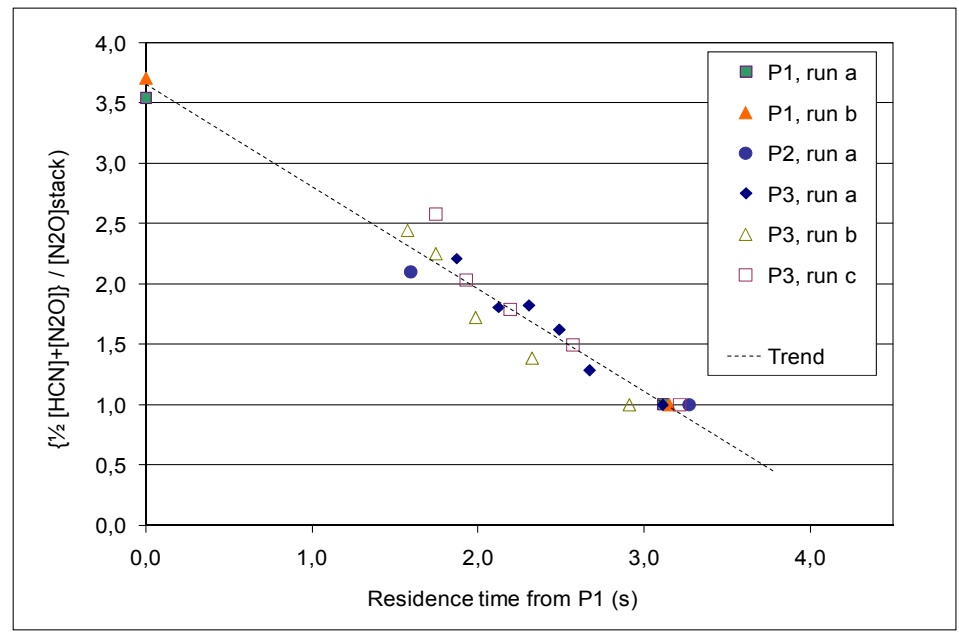

Figure 2: $\quad \mathrm{N}_{2} \mathrm{O}$ and $\mathrm{HCN}$ concentrations as a function of residence time from $\mathrm{P} 1$, expressed as a ratio to the stack $\mathrm{N}_{2} \mathrm{O}$ concentration and $\mathrm{HCN}$ as $\mathrm{N}_{2} \mathrm{O}$-equivalents (dry, standard conditions and normalized to $11 \%$ $\mathrm{O}_{2}$ ). 


\subsection{Step change experiments}

\subsubsection{Effects on temperature and $\mathrm{N}_{2} \mathrm{O}$-emissions}

Lower air-to-fuel ratio's produced higher freeboard temperatures as anticipated. The $\mathrm{N}_{2} \mathrm{O}$-emission shows a strong, decreasing correlation with the freeboard temperature and there seems to be no correlation to the lower air-to-fuel ratio. Figure 3 shows this correlation between $\mathrm{N}_{2} \mathrm{O}$-emission and freeboard temperatures for the first test run. The second test run produced similar results.

The different air-to-fuel ratio's produced a more distinctive effect on the temperatures in the fluidized bed. Figure 4 (first test run of these step change series) shows that different air-to-fuel ratios produce different scatters for the fluidized bed temperature. The figure shows that lower air-to-fuel ratios tend to produce lower bed temperatures thus enlarging the temperature difference between fluid bed and freeboard temperature. Similar bed temperatures produce different clusters for $\mathrm{N}_{2} \mathrm{O}$ emissions depending on the air-to-fuel ratio.

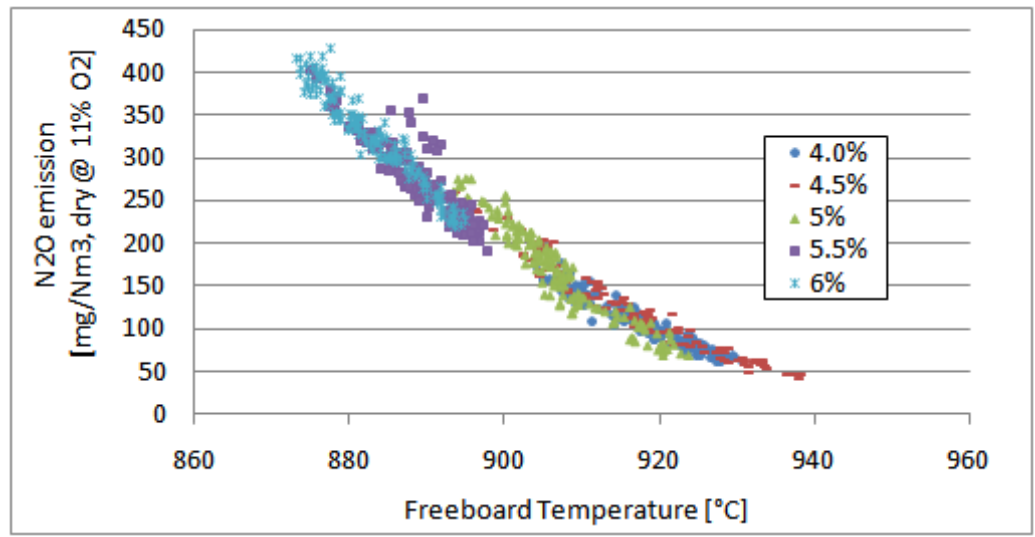

Figure 3: Correlation between $\mathrm{N}_{2} \mathrm{O}$ and freeboard temperature.

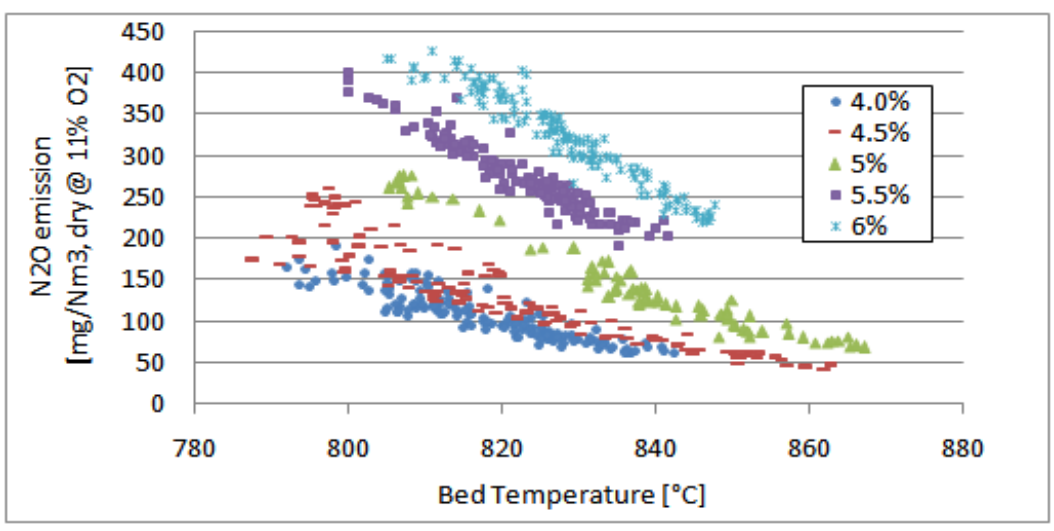

Figure 4: Correlation between $\mathrm{N}_{2} \mathrm{O}$ and bed temperature. 


\subsubsection{Effects on $\mathrm{NO}_{\mathrm{x}}$-emissions}

As there are strict legal limits for the emission of $\mathrm{NO}_{\mathrm{x}}$ in The Netherlands it is important to investigate the effect of the different air-to-fuel ratio's on the emission of $\mathrm{NO}_{\mathrm{x}}$. Higher furnace temperatures proved to produce less $\mathrm{N}_{2} \mathrm{O}$, but these higher temperatures should not give higher $\mathrm{NO}_{\mathrm{x}}$-emissions.

The different air-to-fuel ratio's produced different $\mathrm{NO}_{\mathrm{x}}$-regimes thus enabling operating windows with low $\mathrm{N}_{2} \mathrm{O}$-emissions in combination with low $\mathrm{NO}_{\mathrm{x}}$ emissions. Figure 5 shows the results of the second test run during which no ammonia was injected for $\mathrm{NO}_{\mathrm{x}}$-reduction. The figure shows distinctive clusters for the $\mathrm{NO}_{\mathrm{x}}$-emission as a function of the freeboard temperature for different airto fuel regimes: higher freeboard temperatures produce similar $\mathrm{NO}_{\mathrm{x}}$ emissions if the air-to-fuel ratio is reduced. The air-to-fuel ratio has less influence on the correlation between the $\mathrm{NO}_{\mathrm{x}}$-emission and the bed temperature (figure 6). Here the $\mathrm{NO}_{\mathrm{x}}$-emission appears to be correlated to the temperature of the bed.

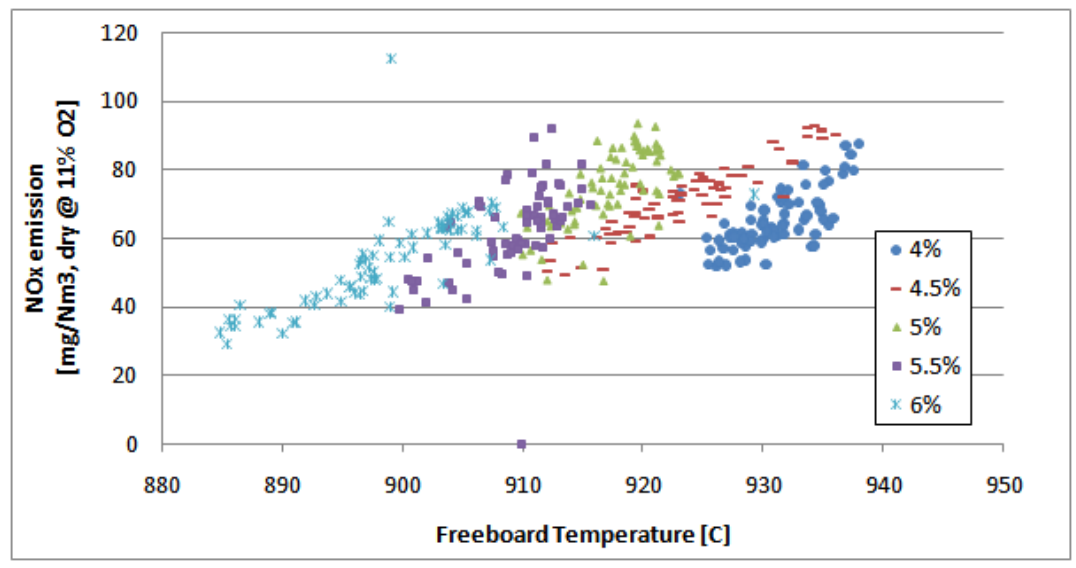

Figure 5: Correlation between $\mathrm{NO}_{\mathrm{x}}$ and freeboard temperature.

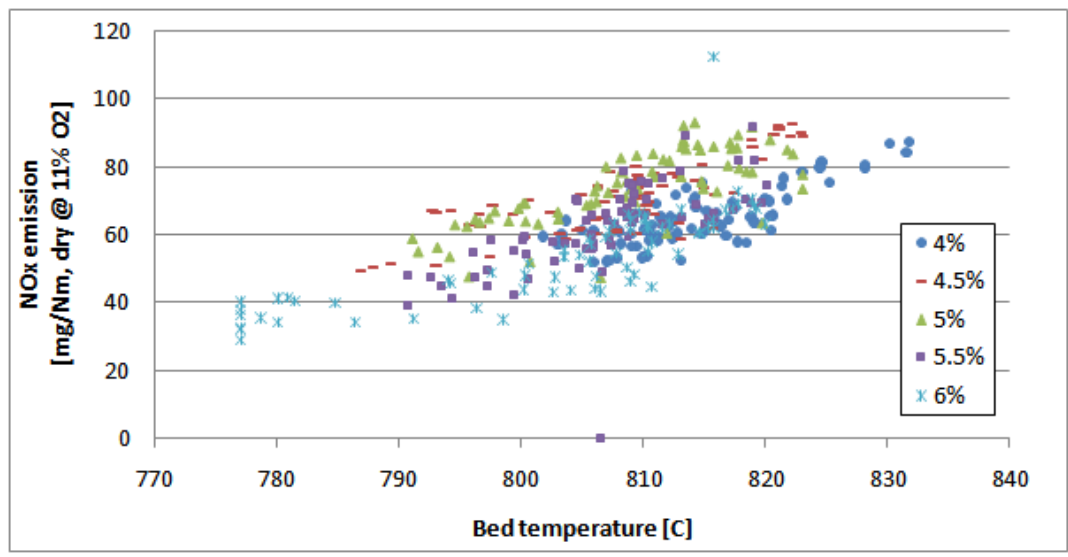

Figure 6: Correlation between $\mathrm{NO}_{\mathrm{x}}$ and bed temperature. 


\subsubsection{Other effects}

The lower air to fuel ratio proved to have no effect on the emission of unburned hydrocarbons. The emission of unburned hydrocarbons remained low at 2 $\mathrm{mg} / \mathrm{Nm}^{3}$ (dry gas, normalized to $11 \% \mathrm{O}_{2}$ ) for all air-to-fuel ratio's and furnace temperatures. For the $\mathrm{CO}$ concentration a slight correlation to the freeboard temperature was found, but no correlation to the air-to-fuel ratio. Nevertheless the $\mathrm{CO}$ concentration remained low in all conditions: ca. $4 \mathrm{mg} / \mathrm{Nm}^{3}$ (dry gas, normalized to $11 \% \mathrm{O}_{2}$ ) at freeboard temperatures of $880^{\circ} \mathrm{C}$ down to $\sim 1 \mathrm{mg} / \mathrm{Nm}^{3}$ at freeboard temperatures of $940^{\circ} \mathrm{C}$. The correlation is very similar to the correlation of $\mathrm{N}_{2} \mathrm{O}$ with the freeboard temperature and could also be an effect of cross sensitivity of the infrared measuring device for $\mathrm{N}_{2} \mathrm{O}$.

The lower air-to-fuel ratio produced a significant decrease in the power consumption of the forced and induced draught fans. Lowering the oxygen excess set point from 5 to $4 \mathrm{vol} \%$, resulted in a decrease of the power consumption of $30 \mathrm{~kW}$ for one incineration line, which is a reduction of approximately $10 \%$ of the normal consumption of the fans. As these fans are the most important power consumers of the installation this is an important result.

\subsection{Simplified chemical reactor model}

The results of the simplified chemical reactor model are presented in figure 7 . For this simulation the concentrations measured during the in-furnace measurements at probing location P1 were used as input for the model. The figure also shows the $\mathrm{N}_{2} \mathrm{O}$ emission that was measured in the stack during the measurements at location P1. The results show that the PSR and PSR+PFR simulation correctly predict the measured end emission for the composition as measured at P1. The simulation also shows that the HCN that is still measured at P1 is quickly decomposed. The PFR-simulation shows a much quicker decomposition of the $\mathrm{N}_{2} \mathrm{O}$. The PFR-like volume V3 is too small to give a significant effect on the final emission.

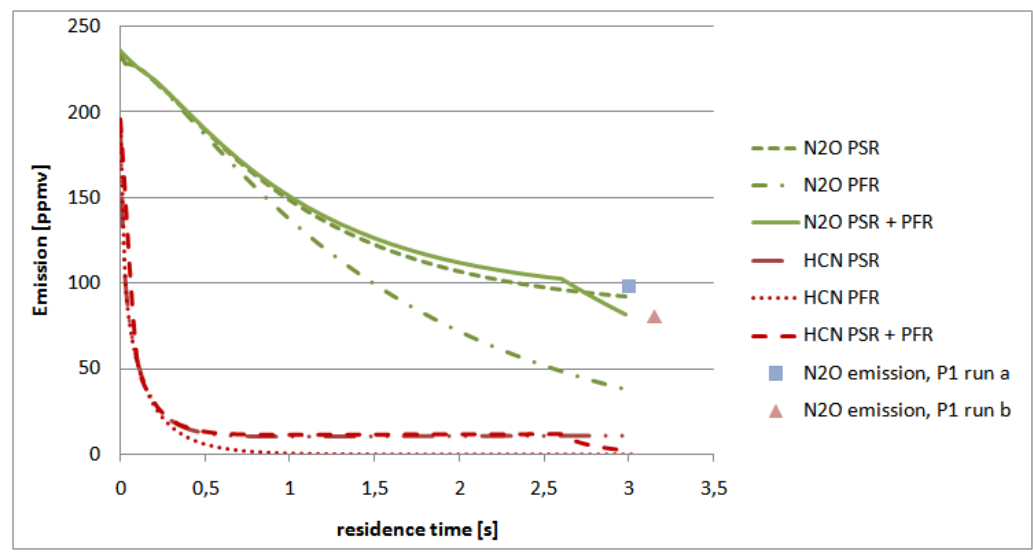

Figure 7: Results of reactor simulation for $\mathrm{N}_{2} \mathrm{O}$ and $\mathrm{HCN}$ decomposition. 


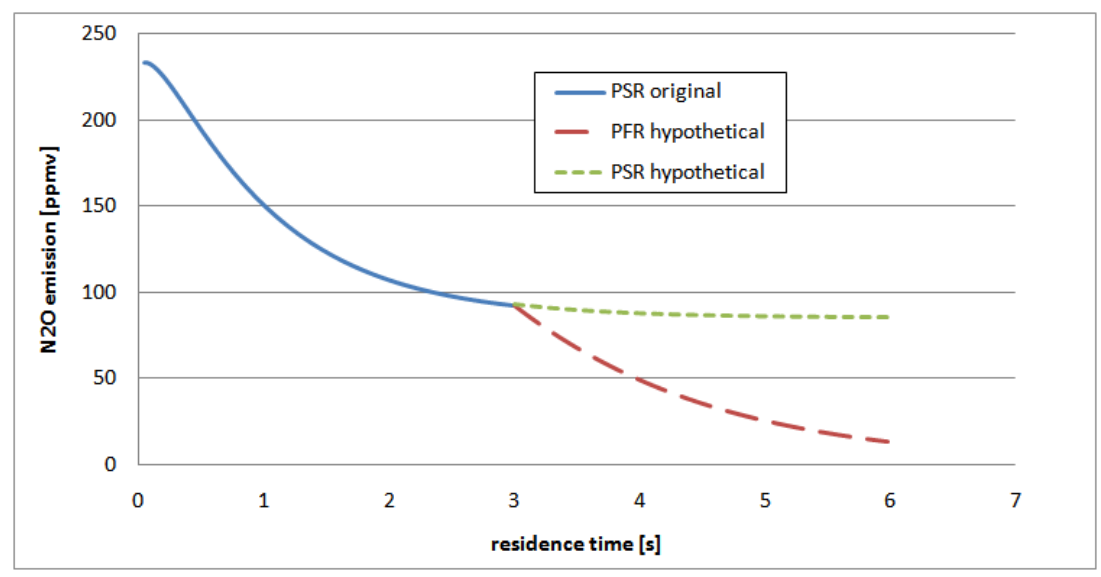

Figure 8: Effect of enlarging the furnace residence time on $\mathrm{N}_{2} \mathrm{O}$-emission.

SNB is currently considering the replacement of the existing steam boilers to increase the energy-efficiency of the installation in combination with a volume extension of the furnace to reduce the $\mathrm{N}_{2} \mathrm{O}$-emission. Therefore also a hypothetical case was simulated were the residence time in the existing furnace would be doubled with another 3 seconds. Figure 8 shows that this extension could be very beneficial to the $\mathrm{N}_{2} \mathrm{O}$-emission provided that hydraulic regime of the extension would meet PFR-conditions. The extension would hardly have any effect if the extension would have PSR-characteristics.

\subsection{Implementation in daily operation}

Already in 2006 a reduction of the air-to-fuel ratio proved to reduce the emission of $\mathrm{N}_{2} \mathrm{O}$. At that time the setpoint for the oxygen excess level was lowered from 6 vol $\%$ to $5 \mathrm{vol} \%$. Based on the results of this study a second reduction was realized in October 2009. Table 2 shows that the first reduction of the air-to-fuel ratio in 2006 reduced the $\mathrm{N}_{2} \mathrm{O}$ emission with $30 \%$. The second reduction of the air-to-fuel ratio reduced the emission even further with another $54 \%$. This is a reduction of $68 \%$ compared to the pre-2006 levels. The table also shows that the $\mathrm{NO}_{\mathrm{x}}$ emission could be maintained at the same level. The emission of $\mathrm{NH}_{3}$ has gradually reduced, but this is the effect of improvements in the ammoniainjection not of changes to the air-to-fuel ratio. The freeboard temperatures have risen slightly with the lower air-to-fuel ratio's while the bed temperatures remained more or less similar. The constant bed temperatures made it possible to operate the furnaces without an increase in the limestone consumption for the capture of $\mathrm{SO}_{2}$ which is very sensitive to higher bed temperatures (higher temperatures: higher consumptions).

In October 2009 regular external emission measurements have been carried out at the new low air-to-fuel ratio and the dioxin emission remained below or at or at the detection limit of $0,01 \mathrm{ng} / \mathrm{Nm}^{3}\left(\right.$ dry, $\left.11 \% \mathrm{O}_{2}\right)$. 
Table 2: Emissions as a function of the air-to-fuel ratio during normal operation (averages of all four incineration lines).

\begin{tabular}{|c|c|c|c|c|c|c|}
\hline Period & $\begin{array}{c}\mathrm{O}_{2} \text { excess } \\
\text { setpoint }\end{array}$ & $\mathrm{N}_{2} \mathrm{O}$ & $\mathrm{NO}_{\mathrm{x}}$ & $\mathrm{NH}_{3}$ & $\begin{array}{c}\text { Bed } \\
\text { Temp. }\end{array}$ & $\begin{array}{c}\text { Freeboard } \\
\text { Temp. }\end{array}$ \\
\cline { 2 - 8 } & $\mathrm{Vol} \%$, wet & \multicolumn{2}{|c|}{$\mathrm{mg} / \mathrm{Nm} 3$, dry at $11{\mathrm{vol} \% \mathrm{O}_{2}}^{\circ}$} & ${ }^{\circ} \mathrm{C}$ & ${ }^{\circ} \mathrm{C}$ \\
\hline Jan. 2004 - Mar. 2006 & 6 & 266 & 38 & 12 & 818 & 902 \\
\hline Apr. 2006 - Sept. 2009 & 5 & 186 & 43 & 8 & 827 & 915 \\
\hline Okt. 2009 - Feb. 2010 & 4 & 86 & 41 & 4 & 825 & 926 \\
\hline
\end{tabular}

\section{Conclusion}

This study shows that the air-to-fuel ratio can play a critical role in the control of $\mathrm{N}_{2} \mathrm{O}$ emissions from the incineration of sewage sludge. A lower air-to-fuel ratio gave $70 \%$ less $\mathrm{N}_{2} \mathrm{O}$ emissions without an increase of the $\mathrm{NO}_{\mathrm{x}}$ emission. The experiments showed that with a lower air-to-fuel ratio the temperature difference between the bed and the freeboard increased. The $\mathrm{NO}_{\mathrm{x}}$ emission correlated strongly with the bed temperature while the $\mathrm{N}_{2} \mathrm{O}$ emission correlated strongly with the freeboard temperature. These different correlations made it possible to find a regime at a lower air-to-fuel ratio where a low emission of $\mathrm{N}_{2} \mathrm{O}$ could be combined with a low emission of $\mathrm{NO}_{\mathrm{x}}$ and a low consumption of limestone in the furnace for binding of $\mathrm{SO}_{2}$. In addition the lower air-to-fuel ratio significantly reduces the power consumption of the forced and induced draught fans.

In-furnace measurements showed high levels of $\mathrm{HCN}$ and $\mathrm{N}_{2} \mathrm{O}$ in the splash zone above the fluid bed. The subsequent reduction of $\mathrm{HCN}$ and $\mathrm{N}_{2} \mathrm{O}$ in the freeboard was modelled and corresponded quite well with the measured stack emissions if the gas flow in the furnace was assumed to show PSRcharacteristics. The model also showed that a higher reduction of $\mathrm{N}_{2} \mathrm{O}$ could be achieved if the gas flow would have plug flow characteristics (PFR). The model showed that longer residence times in the furnace would not significantly reduce the emission of $\mathrm{N}_{2} \mathrm{O}$ if the additional reaction volume would be well mixed. Plug flow conditions are required to achieve a further reduction.

\section{References}

[1] Schipper W.J., Korving L.D., Full-scale plant test using sewage sludge ash as raw material for phosphorus production, Proc. Of the International Conference on Nutrient Recovery from Wastewater Streams, eds. K. Ashley, D. Mavinic \& F. Koch, IWA Publishing, pp 591-598, 2009.

[2] Adam C., Peplinski B., Michaelis M., Kley G., Simon F.-G., Thermochemical treatment of sewage sludge ashes for phosphorus recovery, Waste Management, 29, pp. 1122-1128, 2009.

[3] Werther J., Ogada T., Sewage sludge combustion, Progress in Energy and Combustion Science, 25, pp. 55-116, 1999. 
[4] Sänger M., Werther J., Ogada T., $\mathrm{NO}_{\mathrm{x}}$ and $\mathrm{N}_{2} \mathrm{O}$ emission characteristics from fluidised bed combustion of semi-dried municipal sewage sludge, Fuel, 80, pp. 167-177, 2001.

[5] Ogada T., Combustion and emission characteristics of sewage sludge in a bubbling fluidised bed combustor, PhD thesis, Department of Chemical Engineering I, Technical University of Hamburg-Harburg (Germany), 1995.

[6] Philippek C., Sewage sludge incineration in the circulating fluidised bed. PhD thesis, Department of Chemical Engineering I, Technical University of Hamburg-Harburg (Germany), 1996.

[7] Suzuki Y., Nojima T., Kakuta A., Moritomi H., Pressurized Fluidized Bed Combustion of Sewage Sludge - Energy Recovering from Sewage Sludge by Power Generation System, JSME International Journal, Series B 47, pp. 186-192, 2004.

[8] Abelha P., Gulyurtly I., Cabrita I., Release of Nitrogen Precursors from Coal and Biomass Residues in a Bubbling Fluidized Bed, Energy \& Fuels, 22, pp. 363-371, 2008.

[9] Aho M.J., Hämäläinen J.P., Tummavuori J.L., Importance of Solid Fuel Properties to Nitrogen Oxide Formation through $\mathrm{HCN}$ and $\mathrm{NH}_{3}$ in Small Particle Combustion, Combustion and Flame, 95, pp. 22-30, 1993.

[10] Aho M.J., Hämäläinen J.P., Tummavuori J.L., Conversion of peat and coal nitrogen through $\mathrm{HCN}$ and $\mathrm{NH}_{3}$ to nitrogen oxides at $800^{\circ} \mathrm{C}$, Fuel, 72, pp. 837-841, 1993.

[11] Winter F., Wartha C., Hofbauer H., NO and $\mathrm{N}_{2} \mathrm{O}$ formation during the combustion of wood, straw, malt waste and peat, Bioresource Technology, 70, pp. 39-49, 1999.

[12] Kramlich J.C., Cole J.A., McCarthy J.M., Lanier W.S., McSorley J.A., Mechanisms of Nitrous Oxide Formation in Coal Flames, Combustion and Flame, 77, pp. 375-384, 1989.

[13] Kilpinen P., Hupa M., Homogeneous $\mathrm{N}_{2} \mathrm{O}$ Chemistry at Fluidized Bed Combustion Conditions: A kinetic Modeling Study, Combustion and Flame, 85, pp. 94-104, 1991.

[14] Barisic V., Klingstedt F., Kilpinen P., Hupa M., Kinetics of the Catalytic Decomposition of $\mathrm{N}_{2} \mathrm{O}$ over Bed Materials from Industrial Circulating Fluidized-Bed Boilers Burning Biomass Fuels and Waste, Energy \& Fuels, 19, 2340-2349, 2005.

[15] Kilpinen P., Åbo Akademi University - PCG, Detailed Kinetic Scheme “Kilpinen 97”, 1997: http://www.abo.fi/fak/ktf/cmc. 